\title{
Dwuczęściowy pęcherzyk żółciowy z bliższą częścią wypełnioną kamieniami i zmienioną zapalnie, a dalszą zdrową - opis przypadku
}

\author{
Bi-compartmental gall bladder with the distal part filled with stones and inflamed, \\ and the proximal part not involved - a case report
}

\author{
Andrzej Żyluk, Bernard Piotuch \\ Klinika Chirurgii Ogólnej i Chirurgii Ręki Pomorskiego Uniwersytetu Medycznego w Szczecinie \\ ul. Unii Lubelskiej 1, 71-252 Szczecin \\ Kierownik: prof. dr hab. n. med. Andrzej Żyluk
}

\section{SUMMARY}

Anatomical anomalies of extra-hepatical biliary ducts are fairly common, occurring in about $16 \%$ of patients. The most common anomaly is an atypical course of the cystic duct and its outlet to the common hepatic duct. Anomalies of the gall bladder are less common and rarely presented, due to their minor clinical relevance. The paper presents the case of a female patient with a two-compartment gall bladder, the distal part of which was filled with biliary stones and inflamed, whereas the proximal part contained no stones and was not involved. The operation, although difficult because of the atypical anatomy and inflammatory infiltration, was uneventful, and the patient eventually recovered.

Key words: gall bladder - anatomical anomalies, gall stone disease, cholecystitis.

\section{STRESZCZENIE}

Anomalie anatomiczne przebiegu zewnątrzwątrobowych dróg żółciowych należą do stosunkowo częstych, występując u ok. 16\% pacjentów. Najczęściej zdarza się nietypowy przebieg przewodu pęcherzykowego i jego połączenia z przewodem wątrobowym wspólnym. Anomalie budowy pęcherzyka żółciowego są znacznie rzadsze i nieczęsto opisywane, ze względu na ich mniejsze znaczenie kliniczne. W pracy przedstawiamy przypadek chorej z dwuczęściowym pęcherzykiem żółciowym, którego część dalsza była wypełniona kamieniami i zmieniona zapalnie, a część bliższa nie zawierała kamieni i była zdrowa. Operacja, choć trudna technicznie ze względu na anomalię anatomiczną i naciek zapalny przebiegła bez powikłań, a chora wyzdrowiała.

Słowa kluczowe: pęcherzyk żółciowy - anomalie anatomiczne, kamica żółciowa, pęcherzyk żółciowy - zapalenie.

\section{WSTĘP}

Anomalie anatomiczne przebiegu zewnątrzwątrobowych dróg żółciowych należą do stosunkowo częstych, występując u ok. 16\% pacjentów [1, 2]. Najczęściej zdarza się nietypowy przebieg przewodu pęcherzykowego i jego połączenia z przewodem wątrobowym wspólnym. Rzadziej występujące anomalie to przewody zbaczające i dodatkowe. Anomalie budowy pęcherzyka żółciowego są znacznie rzadsze i nieczęsto opisywane, ze względu na ich mniejsze znaczenie kliniczne (rzadko są powodem jatrogennego uszkodzenia dróg żółciowych) [1, 2, 3].

W pracy przedstawiono przypadek chorej z dwuczęściowym pęcherzykiem żółciowym, którego część górna (dalsza) była wypełniona kamieniami i zmieniona zapalnie, a część bliższa ujściu do przewodu wątrobowego wspólnego nie zawierała kamieni i była zdrowa.

\section{OPIS PRZYPADKU}

Pięćdziesięciotrzyletnia pacjentka zgłosiła się do Szpitalnego Oddziału Ratunkowego z powodu gorączki z dreszczami i trwającymi od 4 dni bólami prawego nadbrzusza. W wywiadzie chora była diagnozowana od roku z powodu cholestazy wewnątrzwątrobowej, rozpoznawanej jako powikłanie po biologicznym leczeniu cefalizumabem reumatoidalnego zapalenia stawów (RZS) z zespołem Sjögrena. W opisach badań USG i tomografii komputerowej brzucha wykonanych w ciągu roku przed przyjęciem do szpitala przewijał się trudny do zweryfikowania twór położony w pobliżu więzadła wątrobowo-dwunastniczego, budzący podejrzenie torbieli dróg żółciowych. Badanie ECPW (endoskopowa cholangiopankreatografia wsteczna) wykonane 5 miesięcy przed przyjęciem nie wykazało odchyleń od stanu prawidłowego, poza stosunkowo wąskim (3 mm) przewodem żółciowym wspólnym. 


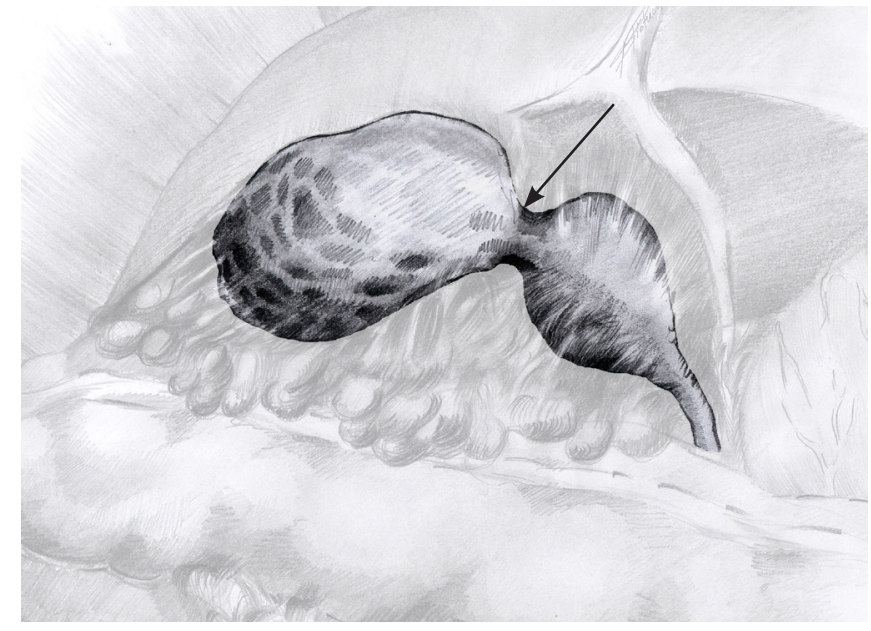

RYCINA 1. Schemat budowy pęcherzyka żótciowego opisywanego w artykule. Strzałką zaznaczono przewężenie oddzielające dwie części pęcherzyka

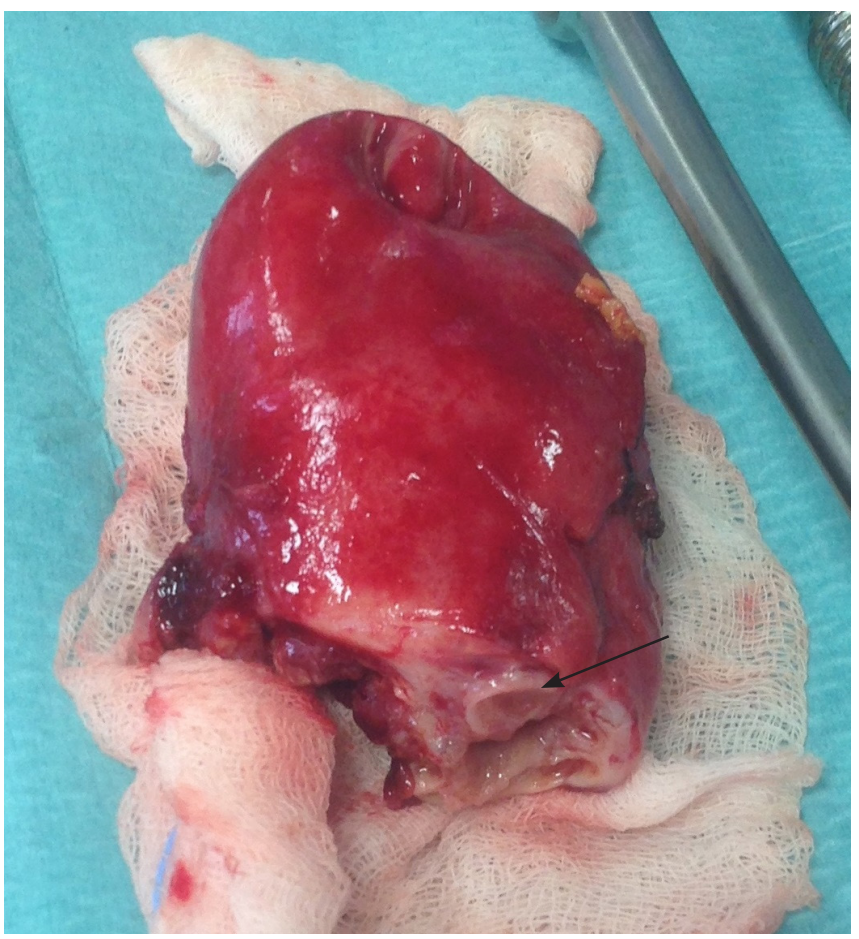

RYCINA 2. Wycięta górna część pęcherzyka opisywanego w artykule. Strzałką zaznaczono przewężenie oddzielające dwie części pęcherzyka

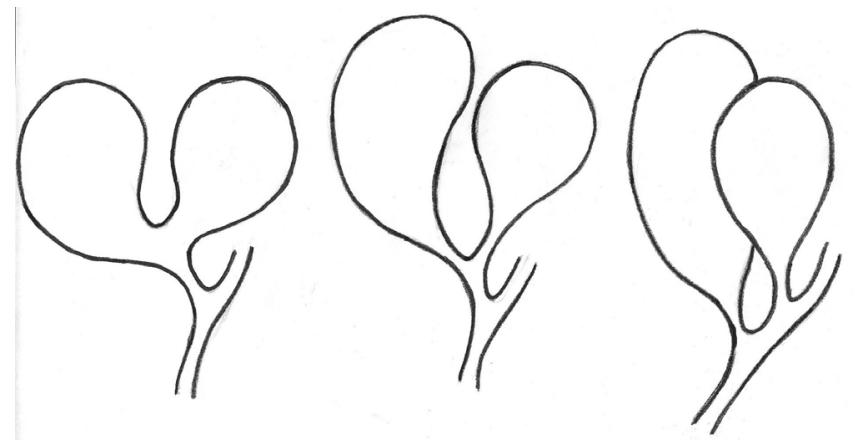

RYCINA 3. Możliwe konfiguracje anatomiczne podwójnego pęcherzyka żótciowego
W badaniu przedmiotowym chora w stanie ogólnym dobrym, wydolna krążeniowo i oddechowo, bez żółtaczki, z temperaturą $38,5^{\circ} \mathrm{C}$. Brzuch miękki, tkliwy w prawym nadbrzuszu, bez objawów otrzewnowych, ale z dodatnim objawem Chełmońskiego. W badaniach biochemicznych podwyższone parametry cholestazy i stanu zapalnego: GGTP $=349 \mathrm{j}$., AST $=54 \mathrm{j}$., ALT $=94 \mathrm{j}$., $\mathrm{ALP}=353 \mathrm{j}$., immunoglobuliny w klasie IgA: 4,40 g/L (norma 0,7-4,0 g/L), stężenie CRP = 204 mg/dL, liczba leukocytów $12 \mathrm{G} /$ L. Badanie USG jamy brzusznej wykazało niepowiększony pęcherzyk żółciowy z kamieniami, o pogrubiałych i miejscowo rozwarstwionych ścianach, z widocznymi pęcherzykami gazu. Obraz budził podejrzenie zgorzelinowego zapalenia.

Wobec takiego obrazu klinicznego, po podaniu antybiotyków (cefazoliny i metronidazolu) zdecydowano o wykonaniu wycięcia laparoskopowego pęcherzyka żółciowego, co nie powiodło się ze względu na naciek zapalny, w jaki był wciągnięty. Wykonano konwersję i jamę brzuszną otwarto $\mathrm{z}$ cięcia pod prawym łukiem żebrowym. Zidentyfikowano pęcherzyk żółciowy w nacieku zapalnym, otoczony siecią i jelitami, wokół niego znajdował się zbiornik treści ropnej, który ewakuowano. Wycinanie pęcherzyka rozpoczęto ostrożnie od dna, ze względu na trudności z identyfikacją nacieczonych struktur anatomicznych. W miejscu, w którym w trakcie preparowania dotarto do przewężenia, pęcherzyk odcięto, spodziewając się, że jest to jego szyja. Jednak dalsze ostrożne preparowanie ujawniło dolną część pęcherzyka o długości ok. $3 \mathrm{~cm}$, kończącą się przewodem pęcherzykowym. Tę część także wycięto, po podwiązaniu przewodu pęcherzykowego. Stwierdzono, że pęcherzyk żółciowy składał się z dwóch części: górnej, większej części, która zawierała kilka kamieni i była zmieniona zgorzelinowo, oraz dolnej, bliższej szyi, która nie zawierała kamieni i nie była zmieniona zapalnie. W trakcie kontroli okolicy zgięcia wątrobowego okrężnicy ewakuowano jeszcze jeden zbiornik ropny. Treść z obu przesłano bo badania bakteriologicznego, które wykazało bakterie $E$. coli wrażliwe na typowe antybiotyki. Badanie wyciętego preparatu potwierdziło obserwację śródoperacyjną: pęcherzyk długości $9 \mathrm{~cm}$ miał dwie komory: górną, większą ( $6 \mathrm{~cm})$, o zmienionej zgorzelinowo ścianie, w której było kilka kamieni i dolną, mniejszą (3 $\mathrm{cm})$, bez kamieni, z prawidłowo wyglądającą śluzówką (ryc. 1 i 2). Połączenie między obiema częściami miało średnicę 0,5 cm (ryc. 2). Przebieg pooperacyjny był niepowikłany i chorą wypisano do domu w 4. dobie pooperacyjnej, jednak w trakcie kontroli ambulatoryjnej stwierdzono ropienie rany, która goiła się przez miesiąc.

\section{DYSKUSJA}

Anomalie budowy pęcherzyka żółciowego występują rzadko i nieczęsto są opisywane ze względu na ich niewielkie znaczenie kliniczne. Zwykle, niezależnie od kształtu i wielkości pęcherzyka żółciowego, jego preparowanie w trakcie cholecystektomii jest ostrożne i pozwala na bezpieczne wycięcie. Powodem trudności i powikłań są natomiast nietypowo przebiegające przewody żółciowe, dochodzące do pęcherzyka w mało spodziewanych miejscach. Opisywany przypadek może 
nie byłby interesujący, gdyby przedstawiał tylko nietypową budowę pęcherzyka. Jednak sytuacja, w której w jednej jego części wytworzyły się kamienie, a w drugiej nie, a tylko jedna część była zmieniona zapalnie, a druga pozostawała zdrowa jest trudna do wyjaśnienia. W piśmiennictwie nie znaleziono opisu podobnego przypadku, ani podobnej sytuacji.

Wrodzone anomalie dotyczące pęcherzyka żółciowego mogą dotyczyć jego lokalizacji, rozmiarów, liczby i kształtu. Występują stosunkowo rzadko, zdarzają się z częstością 1: 3-4 tys. przypadków $[1,2,3]$. Pęcherzyk może być położony w nietypowym miejscu (wrośnięty w wątrobę, schowany w fałdzie otrzewnowym) [4], może być zanikowy, a mimo tego może dawać objawy takie jak w przebiegu kamicy i/lub zapalenia [5], zdwojony, lub może mieć nietypowy kształt. Ponadto, pęcherzyk może być podzielony przegrodami na części [6]. Zdwojenie pęcherzyka żółciowego może mieć postać dwóch osobnych narządów, z których każdy ma własny przewód pęcherzykowy, osobno uchodzący do przewodu wątrobowego wspólnego, dwóch pęcherzyków, ale ze wspólnym przewodem, lub też jednego pęcherzyka składającego się z dwóch połączonych części (ryc. 3) [1]. Opisany w pracy przypadek przedstawia pęcherzyk o nietypowej budowie, składający się z dwóch części połączonych zwężeniem w jego 1 / 3 długości. Ciekawostką jest jednak obecność kamieni i stanu zapalnego tylko w jednejdalszej jego części. Revzin i wsp. podają, że może się zdarzyć, że w zdwojonych pęcherzykach tylko w jednym z nich powstaną kamienie i rozwinie się zapalenie [6]. Opisywana chora miała jednak jeden pęcherzyk, a mimo to kamienie i stan zapalny dotyczył tylko jednej z jego wyraźnych dwóch części.
W piśmiennictwie podkreśla się trudności diagnostyczne w przypadkach anomalii anatomicznych dotyczących pęcherzyka żółciowego. W opisywanym przypadku wyniki badań obrazowych sugerowały jakąś anomalię, najbardziej prawdopodobnie torbiel dróg żółciowych, co jednak nie potwierdziło się w badaniu ECPW, ani śródoperacyjnie. W podobnych przypadkach, kiedy obraz USG (standardowej techniki obrazowania przy diagnostyce kamicy żółciowej) wykazuje jakieś nieprawidłowości lub podejrzenie anomalii, zalecane jest wykonanie cholangiografii tomografii rezonansu magnetycznego (cholangioMR), które jest badaniem dokładniejszym niż ECPW i w dodatku nieinwazyjnym $[3,6]$.

\section{PIŚMIENNICTWO}

1. Pillay Y.: Gallbladder duplication. Int J Surg Case Rep. 2015, 11, 18-20.

2. Shiba H., Misawa T., Ito R., Okhi K., Igarashi T., Yamaga K.: Duplicated gallbladder. Int Surg. 2014, 99 (1), 77-78.

3. Botsford A., McKay K., Hartery A., Hapgood C.: MRCP imaging of duplicate gallbladder: a case report and review of the literature. Surg Radiol Anat. 2015, 37 (5), 425-429.

4. Nayak S.B., Shetty S.D., Surendran S., Jetti R., Kumar N., Sirasangandla S.R.: Double gallbladder completely enclosed in a cystogastric fold of peritoneum. Anat Cell Biol. 2014, 47 (2), 132-134.

5. Yener O., Buldanlı M.Z., Eksioglu H., leblebici M., Alimoglu O.: Agenesis of the gallbladder diagnosed by magnetic resonance cholangiography: report of a case and review of the literature. Prague Med Rep. 2015, 116 (1), 52-56.

6. Revzin M.V., Scoutt L., Smitaman E., Israel G.M.: The gallbladder: uncommon gallbladder conditions and unusual presentations of the common gallbladder pathological processes. Abdom Imaging. 2015, 40, 385-399. 